Journal of Teacher Education for Sustainability, vol. 9, 2008, pp. 21-34

\title{
EDUCATION POLICIES AND TEACHER EDUCATION PROGRAMS: MEETING THE MILLENNIUM DEVELOPMENT GOALS
}

\author{
Nwachukwu Prince Ololube, \\ Oloify Consulting Company \\ Daniel Elemchukwu Egbezor, \\ University of Port Harcourt \\ and Peter James Kpolovie \\ University of Port Harcourt, Nigeria
}

\begin{abstract}
This paper explores the present situation regarding the education policies and teacher education programs in Nigeria in light of the Millennium Development Goals (MDGs) cited in the 2000 United Nations Millennium Declaration. The MDGs declaration helped awaken nations to the need for structural features that empower education policy makers and planners in creating effective educational systems. A survey was used to gather data from teachers and school administrators in Nigeria. The data suggested that both teachers and school administrators are discontented with the lethargic policies and implementation of programs in meeting global standards. In particular, the empiric data could be useful for education policymakers, planners, administrators, and researchers who need information that might help them to improve their activities and deal with the controversial issues.
\end{abstract}

Key words: education policies; teacher education programs; sustainable development; MDGs; Nigeria.

\section{Introduction}

The eight Millennium Development Goals (MDGs), which range from halving extreme poverty, halting the spread of HIV/AIDS to providing universal primary education and eliminating gender disparity in primary and secondary education, preferably by 2005, and at all levels by 2015, form a blueprint which has been agreed by 189 countries. They include the world's leading development institutions. These goals galvanized unprecedented efforts to meet the needs of the world's poorest. A monitor was developed (The MDG Monitor) as a one-stop-shop for information on progress towards the MDGs, globally and at the country level. It is intended as a tool for policy makers, development 
practitioners, journalists, students and others interested in learning about the Goals and in tracking progress toward them (United Nations, 2007a).

Education and training are prerequisites for moving society toward sustainability. Sustainable development is development that meets the needs of the present without compromising the ability of future generations to meet their own needs (ESD ToolKit, n.d). Sustainable development strategies and experiences provide for implementation of the MDGs. In today's world, the vital role of education has become even more significant since the galvanization of the MDGs. Education has an immense impact on human society in reducing the mortality rate among children under five by two thirds and the maternal mortality ratio by three quarters. It is an absolute necessity for the economic and social development of any nation.

Given the diversity in the tiers of government, conflict of interests among them is inevitable. So it is hard to identify policy choices that could serve best the whole country. The way forward typically will involve tradeoffs among competing ends. Managing these tradeoffs effectively is therefore a key mission for decision-makers in the education sector (Mingat, Tan \& Sosale, 2003).

However, a newly published brief notes that to achieve these tradeoffs at the midway point between the adoption of the MDGs in 2000 and the 2015 target date in SubSaharan Africa is not a realistic option. Although there have been major gains in several areas and the Goals remain achievable in most African nations, even the best governed countries on the continent have not been able to make sufficient progress in reducing extreme poverty in its many forms (United Nations, 2007b).

The main focus of this study is to discuss the policy aspects of the education sector and the role of teacher education and its impact on the arrangements for effective education service delivery. It looks at teachers' and school administrators' perceptions of education policies and teacher education programs. The objective is to show how effectively policy issues in education are managed. This quantitative study can make a significant contribution to the discussion amongst policy and decision makers, planners, teachers and administrators in education. In the education sector, developing a shared understanding of the problems and a strategy to address them is critical for achieving results, because such consensus encourages cooperative and synergistic action by the stakeholders who typically play a part in implementing policies in education (Mingat, Tan \& Sosale, 2003).

\section{Review of literature}

\section{Nigeria's national policy on education}

After independence from Britain in 1960, Nigeria's federal government had little influence on education matters at the primary and secondary school levels because that was the constitutional responsibility of the states. This resulted in a multiplicity of educational policies and practices and varying standards of education. Prior to the coming of the British, various Nigerian people had their own education system, as is the case in other countries of the world. According to Fafunwa $(1974,1991)$, the young were taught how to conform to the social customs and traditions of the community and trained for a trade or vocation to make them good citizens. Such education was aimed 
at maintaining continuity in various vocations (especially in medicine, arts, and crafts) and culture by transmitting to successive generations not only accumulated knowledge but standards of beliefs, norms, and values.

However, the turning point in the Nigerian education system was the contribution of the United Nation General Assembly in 1979. Since then, the Nigerian government has pursued education policies aimed at shaping the individual into a sound, useful, and patriotic citizen of the country. The UN General Assembly proclaimed 1979 as the International Year of the Child, which among other things called for free and compulsory primary education, secondary education accessible to all, and the accessibility of higher education. This declaration considerably supported and encouraged the less developed countries of the world to embark on educational development in their countries through diverse educational programs and policies (Ololube, 2006b).

Consequently, a national policy on education was fashioned. The National Policy on Education (NPE) is as much a policy statement as it is a curriculum document. It sets out the goals and aims of Nigerian society, from which are derived the goals of education and subsequently the objective of each level of schooling (Akpe, 1991). The policy document addresses the issues of imbalance in the provision of education in different parts of the country with regard to access, quality of resources, and girls' education. The NPE, popularly known as the 6-3-3-4 System, was introduced in 1977 and revised in 1981 and 1989 respectively (Federal Republic of Nigeria, 1981, 1989). It marked a radical departure from the British system of education that Nigeria inherited at independence in 1960. Nigeria adopted the American system of 6 years of primary education, 3 years of junior secondary school, 3 years of senior secondary school, and 4 years of university education.

The 6-3-3-4 system of education as copied from the United States was adopted in order to achieve or at least further the following national goals:

- The inculcation of national consciousness and unity;

- The inculcation of the right type of values and attitude for the survival of the individual and Nigerian society;

- The training of the mind in the understanding of the world around it;

- The acquisition of appropriate skills, ability and competencies, both mental and physical, to equip the individual to live in and contribute to the development of his society (Federal Republic of Nigeria, 1989: 8).

This underlies the phenomenal expansion of education at all levels and the vigorous experimentation in all aspects of education within the last two decades in Nigeria. In support of this, the government provided educational opportunities for all citizens at the primary, secondary, and tertiary levels. The government placed emphasis on the quality of education and established nationally acceptable standards and practices in order to ensure even progress and development throughout the country (Federal Ministry of Education, 1995). For example, new policies contained in the NPE (2004) proposed a system of education that would be cost-effective while simultaneously making students more marketable by equipping them with ICT skills for a wide range of employment opportunities (Ololube, 2007; Oduolowu, 2007). The implementation of these objectives became problematic due to the need to achieve uniformity throughout the country, lack of capacity for planning and management, and lack of the necessary resources. The system in general faced a teacher shortage problem, particularly with regard to teachers who possessed the appropriate qualifications, expertise and experi- 
ence to teach effectively. These difficulties have been most pronounced at the foundation levels of education. Both the primary and secondary school levels have been negatively affected. The basic infrastructure in schools, such as classrooms, laboratories, workshops, sporting facilities, equipment, libraries, were in a state of total decay. Thus the physical condition of most schools is reported to be pathetic (Moja, 2000; Ololube, 2005a; Yusuf, 2002).

\section{Teacher education and training}

The need for an effective education policy is not new, but the demand for it has been growing in recent years. Attending to outcomes is consistent with everyone's concern about the ultimate objective of investing in education and teacher education to produce literate citizens and skilled labor adequate to match demand in the labor market (Mingat, Tan \& Sosale, 2003). More importantly, an effective teacher education policy and teachers' roles in the educative process are central to basic education. The teaching force is the foundation of quality and relevance of education at all levels (Oduolowu, 2007). The best way to enhance instruction in order to meet the MDGs target of 2015 is through effective teacher education programs, which are key to understanding both teaching and learning. Such programs are meant to help individual teachers grow and develop as teachers, provide them with the skills and professional abilities to motivate children to learn, and to assist them in acquiring the right understanding of the concepts, values, and attitudes needed, not only to manage classroom instruction but also to contribute to the society in which they are born, grow, and live. Thus, teacher education is designed to produce a highly motivated, sensitive, conscientious, and successful classroom teacher who will handle students effectively and professionally for better educational achievement.

In Nigeria, reasonable preparations have been made to improve teachers' professional development through the establishment of colleges of education, both at the federal and state levels. Institutes of education and faculties of education in various universities have also been established to provide effective and professional teacher education programs. In such institutions, students receive training that will help them become teachers capable of shouldering responsibilities, showing initiative and being good models for their future pupils (Ololube, 2006b, 2007).

The objective of Nigerian teacher education as contained in the NPE (Federal Republic of Nigeria, 1981) which was revised in 1989 is as follows:

- To provide highly motivated, conscientious and efficient classroom teachers for all levels of our educational system;

- To encourage further the spirit of inquiry and creativity in teachers;

- To help teachers to fit into the social life of the community and society at large and enhance their commitment to the national objective;

- To provide teachers with adequate intellectual and professional background for their assignments and to changing situations, not only in the life of the country but also in the wider perspective;

- To enhance teachers' commitment to the teaching profession (Federal Republic of Nigeria, 1989: 38). 
It is interesting to note that the aforementioned aims and objectives of teacher education in Nigeria are meant for all levels of education and sound very promising in moving the country forward.

The NPE (Federal Republic of Nigeria, 2004) Section 9, sub-section 65 states that at the Nigeria Certificate in Education (NCE) and degree levels, teacher education programs will be expanded to cater for the requirements of vocational, technical, and commercial education. The sub-section also recognizes the problems with Nigeria's education system and the federal government's promises to implement the commission's recommendations by providing physical facilities and qualified staffs in schools. Sub-section 67 acknowledges the federal government's willingness to direct the universities to work out a program to make it possible for suitable qualified holders of the NCE to complete a degree in education at the university in two years instead of the present three years. Sub-section 73 states that teacher education will continue to recognize changes in methodology and curriculum and promises that teachers will be regularly exposed to innovations in their profession; in-service training will be developed as an integral part of continuing teacher education. The NPE further argues in sub-section 74 that

Regardless of efficiency of the pre-service teacher training, there will necessarily be areas of inadequacies. In-service education for teachers will continue to fill these gaps. For instance, library service education, evaluation techniques, guidance and counseling, etc. will be systematically planned so that successful attendance of a number of such courses will attract incremental credit and/or count towards future advancement (p. 51).

Even with all these statements and programs in place, little has been achieved. However, the goal for which these moderate preparations were intended has had no meaning because we have always expected that the products of teacher education institutions will be employed to handle the instructional processes in the Nigerian schools for which they have been trained. Yet, incompetent teachers are still employed to carry out teaching. Educators in Nigeria (e.g., Adigwe, 1991; Ololube, 2005b) have argued that the falling educational standards can be attributed to the use of teachers who are unqualified for instructional purposes, which include those with general education (academic) qualifications, such as BSc., BA., MSc., and MA degrees, etc.

\section{Impediments to effective education policy and teacher education programs in Nigeria}

There are several barriers to the successful implementation of education policies and teacher education programs in Nigeria. We shall limit ourselves to a few:

\section{Political}

Politics cannot be divorced from education, culture, society, religion and economics. Education policies will be difficult to implement without political will and considerations. Over the past decade, Nigeria has been plagued by frequent political unrest. This political instability has had negative effects on the education system. Although education had been in crisis for many years, the situation has recently been made worse by 
frequent strikes staged by students, faculty, and teachers (Moja, 2000). For instance, the past civilian president (Chief Olusegun Obasanjo) forced university students to stay at home for one academic session for fear that they might disrupt his third time political agenda.

The majority of education institutions in Nigeria are influenced by the political environment that has created a crisis in the academic community. Appointments of friends and relatives into sensitive positions without due qualifications has adversely affected the educational system. This is made worse during the past two decades, which witnessed a huge turn out of graduates from the education system into the labor market. Dozens of university graduates lined up for a single opening, and many more for less specialized positions. Under such conditions, preferential treatment, ethnic and family favoritism, and bribery flourished in employment decisions. The overwhelming influence of politicians in recommending persons for appointment into faculty positions makes such a situation even more frightening, as merit does not guide staff recruitment and selection.

Obiakor, Maltby, and Ihunnah (1990) outlined some political problems that impede education policies and their implementation in Nigeria. These problems include, but are not limited to the following:

- There is less emphasis on national interest/patriotism;

- Foreign nations set the tone in their development aids and transfer of technology;

- The tribe or religion is given more consideration over political manifestos;

- The frequency of transitional government;

- Political leaders find it difficult to hand over power without causing bloodshed;

- Political accountability of the ruled is not considered;

- There is incessant politization of educational, cultural, societal, religious and economic matters;

- Political corruption or structural failure;

- Lack of trust for politicians.

\section{Economic}

Much of the difficulty faced by education in general and the teacher education sector in particular lies in the weak economic situation of the country. Embezzlement (theft of public resources by public officials), corrupt practices and serious neglect are the order of the day in the economy including the education sector. Thus, academic standards have fallen tremendously over the years. Educational achievements amongst students are purely self-development with a little assistance from some sincere teachers. Presently, almost all the instructional materials that aid teaching and learning, i.e. textbooks, classrooms, laboratory equipment, access to the Internet (computers) and other ICT equipment, etc. are in short supply. To make matters worse, inconsistency in economic policies and the provision of electricity have hampered the growth of education in Nigeria (Ololube, 2006b).

Another formidable obstacle to the use of information and communication technology is infrastructure deficiencies. Electrically powered equipment and instructional materials are made to function with other infrastructure such as generators under "controlled conditions". For the past fifteen years Nigeria has experienced difficulty provid- 
ing a stable and reliable supply of electricity country-wide. When electrical supply is not stable and constant, it is difficult to keep high-tech equipment such as computers functioning, especially under the extreme weather conditions found in Nigeria. The high levels of dust during the dry season also shorten the life spans of electronic equipment (Aduwa-Ogiegbaen \& Iyamu, 2005).

A good number of teachers/lecturers are now either contractors supplying goods and services to schools or engaging in commercial business within and outside the school to the detriment of their academic calling and purpose. For example, some of them have turned their offices into commercial centers either offering typesetting services or engaging in buying and selling petty goods. Some of them argue that they have had to resort to this "moonlighting" to augment their salaries, which are meager and irregular. The education institutions that are established to promote intellectual excellence, good virtues, etc. have deviated from their traditional obligations of teaching, research, and development of manpower. We are faced daily with reports of students caught in armed robbery, rape, assassination, etc. A majority of these institutions have seemingly forgotten their goals and have instead allowed social and political factors to create crises in their academic communities. It is a known fact that no segment of the education system gets its entire approved annual budget (Olujuwon, 2003). Thus, researchers and commentators (Ololube, 2006a,b; Ololube, 2007; Lawal, 2003) persistently argue that Nigerian public schools at all tiers are experiencing dwindling standards in the quality of education as a result of poor quality education policies and programs, and the graduates of these institutions are unemployable and are treated as such both internally and globally.

\section{Financial}

Education funds refer to budgetary allocations that are readily available or that are going to be made available at a stated time by governments or institutions for the purpose of paying salaries, allowances and benefits, and the building and provision of educational infrastructures to aid teaching and learning. Education funding in Nigeria has gradually been on the rise culminating at an increased allocation of $11 \%$ (N166bn) in 2006. The total allocation for 2007 was (N186bn) up from N166bn in 2006. This represents a growth of $12 \%$. The bulk is targeted at human resource capacity building, the upgrading of facilities in educational institutions and bold new reforms to improve the quality of and access to education. This figure excludes intervention through the Universal Basic Education Commission, which provides additional resources of N35 bn to state and local governments to support basic education. These additional resources are to be used to upgrade infrastructure and teaching facilities in primary schools across the nation and to fund other initiatives (Africa Research Bulletin, 2006). Thus Nigeria is struggling to meet the $26 \%$ allocation recommended by UNESCO as a means of attaining quality education and education for sustainable development from 2005 to 2014. Despite improved budgetary allocation to the education sector in Nigeria, the condition of education remains worrysome. Conditions of facilities are still a far cry from acceptable basically due to past under-funding and systemic corruption (Ololube, 2007; Ololube, 2006c; Samuel, 2006).

In spite of the federal government's specification in the National Policy on education that "teacher education will continue to be given a major emphasis in all our 
education planning because no education system can rise above the quality of its teachers" (Federal Republic of Nigeria, 1989), education has continued to be grossly under funded. Inadequate financing from both federal and state governments militates against the progress of the colleges of education and teacher education generally, and this indicates that professionalism is a very remote possibility (Lawal, 2003). Equally, according to Odenigbo (n.d), financing educational ventures in Nigeria, especially since the newly created states, has been very poor, to say nothing of training the teachers/tutors at all levels of education.

Overall, government funding of education has been inadequate. The funding of education is shared among different levels of government and supplemented by funds from other sources such as business, community organizations, and levies charged to parents. The revenue collected through fees constitutes an insignificant proportion of the revenue of the institutions. Inadequate funding of education has been one of the most significant causes of the low quality of much of the education offered at all levels. Funding allocations have been in flux during the last two to three decades. On the whole, there has been a drop in the funding level of education.

\section{Methodology}

\section{Research hypotheses}

The aim of this research is to identify the Nigerian teachers' and school administrators' perception of the education policies and teacher education programs for effective education service delivery towards meeting the MDGs. Specifically, the study addressed three null hypotheses:

- $\mathrm{H}_{1}$. There are no statistically significant differences between the perceived impact of education policies realized in Nigeria and the MDGs;

- $\mathrm{H}_{2}$. There are no statistically significant differences between the perceived impact of teacher education programs implemented in Nigeria and the MDGs;

- $\mathrm{H}_{3}$. There are no statistically significant differences in the opinions of research participants based on their background information (gender, age, specialization, status).

\section{Participants}

The research sample for this study consisted of teachers and school administrators (principals) drawn from 20 secondary public schools out of the 146 in Rivers State of Nigeria. A total number of 205 respondents, which were randomly selected, were engaged in the research. The majority of respondents $(68.3 \%)$ were male, while $65(31.7 \%)$ were female. Regarding the age, $47(22.9 \%)$ of the respondents were $25-30$ years old, $84(41.0 \%)$ were $31-40$ years old and $74(36.1 \%)$ participants were 41 years old and older. Considering the specialization of respondents, $159(77.6 \%)$ of them had specialization in the science and social sciences, while specialty of $46(22.4 \%)$ respondents was the humanities. At the same time, 170 (82.9\%) of them were teachers, while $35(17.1 \%)$ were school administrators (principals). 


\section{Research instrument}

This study employed a survey research design. The survey was designed following the characteristics of a good questionnaire: relevance, consistency, usability, clarity, quantifiability, and legibility (Nwagwu, 1997: 93-94). The contents of survey were validated by colleagues experienced in designing research surveys. The respondents were asked to determine the impact of the different factors on education policies and teacher education programs in Nigeria using a four-point Likert-type scale. The scale anchors were 1 = strongly disagree to 4 = strongly agree. The survey consisted of a set of items, all of which were considered as having approximately equal "attitude value" and to which subjects responded with a degree of agreement or disagreement. The survey included three major sections: (a) the respondents' background information, (b) respondents' perception of education policies and the factors inhibiting the movement toward MDGs, and (c) respondents' perception of teacher education programs and the factors inhibiting the movement toward MDGs. The data were gathered on two occasions between February-March and September-November 2006 through direct contact with the respondents to explain the aim and objectives of the research. The coherence and reliability of items in each section was examined by Cronbach's alpha: background information ( 9 items) $\alpha=.85$, education policies factors ( 7 items) $\alpha=.92$ and teacher education programs factors ( 8 items) $\alpha=.88$. Statistic analysis (mean, standard deviation, ANOVA) was conducted using the Statistical Package of the Social Sciences (SPSS) version 15.0 software program (N-205) (Bryman \& Cramer, 2001; Saunders, Lewis \& Thornhill, 2000; Okeke \& Kpolovie, 2006).

\section{Results}

\section{Perception of education policies and teacher education programs}

Statistical analysis for this study began with an analysis of mean and standard deviation for the respondents' answers. Table 1 shows the mean value and standard deviation for variables of education policies and teacher education programs. The respondents' answers showed that the education policies and teacher education programs of Nigeria are not making any impact towards meeting the MDGs. One sample t-test was used to test hypotheses 1 and 2. The analysis led toward the rejection of hypotheses 1 and 2.

Table 1. Mean, standard deviation and one sample t-test analysis of variables

\begin{tabular}{lccccc}
\hline Variables & Mean & Std. D. & $\mathrm{t}$ & $\mathrm{df}$ & Sig. (2-tailed) \\
\hline Education Policies Factors & 3.09 & .58 & 62.9 & 204 & $.000^{* * * *}$ \\
\hline Teacher Education Programs Factors & 3.15 & .46 & 69.7 & 204 & $.000^{* * *}$ \\
\hline
\end{tabular}

$D f=N-1, \cdots * p<0.001$ 


\section{Opinions of participants determined by their background}

To test to what degree differences exist between the respondents coming from different backgrounds a one-way-analysis of variance (ANOVA) was set at $\mathrm{p}<.05$. There were no statistically significant differences in respondents' opinions based on gender, age, area of specialization, and status. Thus, hypothesis 3 was accepted (see Table 2).

Table 2. Analysis of variance for participants' background information

\begin{tabular}{|c|c|c|c|c|c|c|c|}
\hline \multicolumn{2}{|c|}{ Participants' background information } & $\mathbf{n}$ & $(\%)$ & Mean & SD & F ratio & Sig. \\
\hline \multirow[t]{2}{*}{ Gender } & Male & 140 & 68.3 & 3.11 & .73 & 1.68 & .196 \\
\hline & Female & 65 & 31.7 & 2.98 & .33 & & \\
\hline \multirow[t]{3}{*}{ Age } & $25-30$ & 47 & 22.9 & 3.09 & .58 & 1.30 & 274 \\
\hline & $31-40$ & 84 & 41.0 & 2.99 & .77 & & \\
\hline & 41-above & 74 & 36.1 & 3.15 & .46 & & \\
\hline \multirow[t]{2}{*}{$\begin{array}{l}\text { Area of } \\
\text { Specialization }\end{array}$} & $\begin{array}{l}\text { Sciences \& } \\
\text { Social Sciences }\end{array}$ & 159 & 77.6 & 3.02 & .64 & 1.45 & .262 \\
\hline & Humanities & 46 & 22.4 & 3.24 & .57 & & \\
\hline \multirow[t]{2}{*}{ Status } & Teachers & 170 & 82.9 & 3.07 & .64 & .95 & .325 \\
\hline & School administrators & 35 & 17.1 & 3.09 & .61 & & \\
\hline
\end{tabular}

\section{Discussion and conclusions}

The study discussed the policy aspects of the education sector and the role of education and teacher education and their impact on the arrangements for effective education service delivery. It looked at teachers' and school administrators' perceptions regarding education policies and teacher education programs and the factors that militate against them in meeting the MDGs specifically in Nigeria.

The empirical results point to the fact that the respondents are greatly dissatisfied with the insufficient funding, embezzlement, absence of infrastructure and ICT equipment and the slow pace of the integration of ICT into education and teacher education programs, ineffective administration and planning, politization of policies and programs along with student teacher selection processes, which drastically affects the standard of education and teacher education programs. The outdated curriculum is cause for concern. Likewise the respondents are dissatisfied with the recruitment and selection processes in general. They are also not pleased especially with the implementation, evaluation, and control stages of policies and programs. The empirical evidence provided shows that the education policies and teacher education programs fell short of meeting internationally accepted standards. No significant differences exist in the respondents' opinion considering their age, gender, specialty, or status. The findings in this article reinforce the previous studies on the standard of education and teacher education in Nigeria (e.g., Obiakor, Malty \& Ihunnah, 1990; Lawal, 2003; Ololube, 2006b, 2007; Oduoluwu, 2007).

The NPE of Nigeria could be strengthened with quality regulatory roles, increased enrolment into the education and teacher education programs with quality training, improved funding, reviewed curriculum contents to include new ones in line with glo- 
bal demands, effective education administration and planning, continuous evaluation of policies and programs, innovative approaches of teaching and proper adherence to policies and programs implementation. With this in place, the entire education system would benefit from coherent national policy development rather than piecemeal reforms. The revision of education policies is being considered as a long-term goal, due to other pressing needs. Successful implementation will depend on the availability of adequate resources and the sharing of responsibility amongst different levels of government (Moja, 2000).

Developing countries spend much of their time debating on causes of their perennial socio-economic and political setbacks. It is unfortunate that leaders dissociate the fate of democracy from the quality of intellectual leadership by pigeonholing talented specialists, blaming colonial dominance and world powers for endemic socio-economic problems and acting as tribal/regional leaders rather than national leaders. In Nigeria, policy establishment negatively correlates with policy and program implementation. Education and teacher education policies intended for national development are not well implemented. Therefore, Nigeria and many developing countries need to continuously evaluate their education policies and teacher education programs. According to Obiakor, Maltby, and Ihunnah (1990), continuous evaluation of education policies and teacher education programs will enable policy and program planners and evaluators to:

- Detect how well the policy has helped in restructuring and formulating a new society;

- Discover how well the policy affects the culture, society, economy and politics of the people;

- Detect if the policy promotes democratic ideas which emphasize (a) the importance of the individual, (b) social responsibility, and (c) freedom and liberty;

- Find out how the policy reflects the education, training and complex organization required by modern technology;

- Put the blame where it belongs, i.e, in the hands of policy/program administrators;

- Influence curriculum change and planning to highlight (a) objectives, (b) subject matter, (c) methods and organization, and (d) evaluation (p. 13).

Moreover, since Nigeria is in dire need of development, Nigerian education and teacher education programs are so important that all avenues should be explored in order to increase the soundness of the nation's education system at all levels. In order for a nation to develop, its education must be based on a solid foundation and all facilities needed for enhancing any educational program must be provided. These include the recruitment of professional and academically qualified teachers who are interested in the educational development of the nation. A country can only develop significantly and attain greater heights in the committee of nations through comprehensive education and teacher education programs. The education sector should assume a more active social role in producing research, in debates and in teaching, as this will promote the development and general appreciation of the education system. All teacher education and training must include content that helps teacher trainees to interpret and influence current phenomena in society, economy, culture and working life. Prospective teachers must also gain an awareness of the ethical responsibility intrinsic to the teaching profession not only in theory but also through experience. The models assimilated during education constitute a crucial basis for future work. 
According to Yusuf (2002), the main objectives of education are to develop awareness, knowledge, attitudes, skills, evaluate ability and encourage full participation in national development. Thus, the most effective strategy for making steady and sustainable development toward the MDGs is to serve the goals of education and teacher training in an integrated way. These conditions will create level playing ground thus giving education institutions incentives to adopt new and sustainable technologies that will diversify graduates who have higher-value education. Policy action and increased investment in the critical arenas of sustainable education policies and teacher education programs will be essential for responding effectively and responsibly to reach the MDGs.

\section{Implication for research and practice}

This research has both practical and conceptual implications that would facilitate a broad understanding of the issues surrounding education policies and teacher education programs in line with meeting the MDGs. The presented unique study both provides support for researchers and practitioners and adds to the emerging body of knowledge regarding this domain of study. In addition, the findings of the study suggest that studies involving the effectiveness of education policies and teacher education programs in the developing world need not stop at this stage. However, there are limitations to this study as the opinion of 205 respondents out of thousands of teachers and school administrators in Nigeria cannot be considered all-inclusive.

This study also has implications for government, administrators and policy makers as well as instructors and other entities that are involved in effectiveness, quality improvement and development of education in Nigeria in particular and Africa in general. In closing, a successful inclusion of proactive decision and policy implementation of education can make an important contribution to achieving the MDGs, by establishing sustainable positive incentives for educational policy production in developing countries.

\section{References:}

Adigwe, J. C. (1991) Problem-solving processes of pre-service chemistry teachers in Nigeria. Research in Science and Technological Education, 9(1), 107-120.

Aduwa-Ogiegbaen, S. E. \& Iyamu, E. O. S. (2005) Using Information and Communication Technology in secondary schools in Nigeria: Problems and prospects. Educational Technology and Society, 8(1), 104-112.

Africa Research Bulletin (2006) Economic Financial and Technical Series. Vol. (43)9, September 16th-October 15th 2006. Retrieved December 29, 2007 from http://www.blackwell-synergy.com/doi/pdf/10.1111/j.1467-6346.2006.00481. $\underline{\mathrm{x} \text { ? cookieSet }=1}$

Akpe, C. S. (1991) Choice of teaching subjects in pre-service teacher education in Nigeria. Journal of Education for Teaching, 17(2), 213-219.

Bryman, A. \& Cramer, D. (2001) Quantitative Data Analysis with SPSS Release 10 for Windows: A Guide for Social Scientists. Philadelphia: Routledge: Taylor and Francis Group.

ESD Toolkit (n.d). Introduction. Retrieved December 29, 2007 from http://www.esdtoolkit.org/discussion/default.htm 
Fafunwa, A. B. (1974) The History of Education in Nigeria. Ibadan: Macmillan Publishers.

Fafunwa, A. B. (1991) The History of Education in Nigeria. Ibadan: NPS Educational Publishers.

Federal Ministry of Education (1995) Educational Data Bank. Lagos: Federal Ministry of Education.

Federal Republic of Nigeria (1981) The National Policy on Education. Lagos: Government Printer.

Federal Republic of Nigeria (1989) The National Policy on Education (Revised). Lagos: NERC Press.

Federal Republic of Nigeria (1995) The National Policy on Education (Revised). Lagos: NERC Press.

Federal Republic of Nigeria (2004) The National Policy on Education (3rd ed.). Lagos: NERC Press.

Lawal, H. S. (2003) Teacher education and the professional growth of the 21st century Nigeria teacher. The African Symposium, 3(2), July 2003.

Mingat, A., Tan, J. \& Sosale, S. (2003) Tools for Education Policy Analysis. New York: World Bank.

Moja, T. (2000) Nigeria Education Sector Analysis: An Analytical Synthesis of Performance and Main Issues. Produced for the World Bank in January 2000. Retrieved December 29, 2007 from http://siteresources.worldbank.org/ NIGERIAEXTN/Resources/ed sec analysis.pdf

Nwagwu, N. A. (1997) The environment of crises in the Nigerian education system. Comparative Education, 33(1), 87-95.

Obiakor, F. E., Maltby, G. P. \& Ihunnah, A. C. (1990) Special Education Policies in Nigeria: Cultural, Socio-Economic and Political Issues. Retrieved December 31, 2007 from http://www.eric.ed.gov/ERICDocs/data/ericdocs 2 sql/content storage 01/0000019b/80/20/77/d0.pdf

Odenigbo, A. I. (n.d) Teacher Development and Curriculum and Effective Secondary School Education in Nigeria. Retrieved March 30, 2006 from http://www.worldbank.org/afr/seia/conf 0603/5.0611-Nigeria.pdf

Oduolowu, E. A. (2007) A comparison of The Universal Basic Education (Ube) Program in Nigeria and the Grundskola of Sweden. The African Symposium, 7(1), 51 60.

Okeke, E. C. \& Kpolovie, P. J. (2006) Basic Research Methods and Statistics. Owerri: Springfield Publishers.

Ololube, N. P. (2005a) Benchmarking the motivational competencies of academically qualified teachers and professionally qualified teachers in Nigerian secondary schools. The African Symposium, 5(3), 17-37.

Ololube, N. P. (2005b) School effectiveness and quality improvement: Quality teaching in Nigerian secondary schools. The African Symposium, 5(4), 17-31.

Ololube, N. P (2006a) The impact of professional and non-professional teachers' ICT competencies in secondary schools in Nigeria. Journal of Information Technology Impact, 6(2), 101-118.

Ololube, N. P. (2006b) Teacher Education, School Effectiveness and Improvement: A Study of Academic and Professional Qualification on Teachers' Job Effectiveness in Nigerian Secondary Schools. Doctoral Dissertation, December 2006. University 
of Helsinki, Faculty of Behavioral Sciences, Department of Applied Sciences of Education, University of Helsinki Press.

Ololube, N. P. (2006c) Teachers Instructional Material Utilization Competencies in Secondary Schools in Sub-Saharan Africa: Professional and non-professional teachers' perspective. In Conference Proceedings of the $6^{\text {th }}$ International Educational Technology Conference.

Ololube, N. P. (2007) The relationship between funding, ICT, selection processes, administration and planning and the standard of science teacher education in Nigeria. Asia-Pacific Forum on Science Learning and Teaching, (8)1, Article 4.

Olujuwon, T. (2003) Education in Nigeria: A Futuristic Perspective. In Conference Proceedings of 4th World Conference of the International Consortium for Educational Development 3-6 July, Perth, Western Australia, 1-8.

Samuel, W. (2006) Education Financing, Overcoming the Challenges. Retrieved February 10, 2006 from http://www.thisdayonline.com/nview.php?id=40097

Saunders, M., Lewis, P. \& Thornhill, A. (2000) Research Methods for Business Studies (2nd ed.). Harlow: Prentice Hall.

United Nations (2007a) UN Millennium Development Goals. Retrieved December 27, 2007 from http://www.un.org/millenniumgoals/

United Nations (2007b) The Millennium Development Goals Report 2007. Retrieved December 26, 2007 from http://mdgs.un.org/unsd/mdg/Resources/Static/Products/ Progress2007/UNSD MDG Report 2007e.pdf

Yusuf, K. (2002) The need for environmental education in the teacher education programme in Nigeria. The African Symposium, 2(4), December 2002.

\section{Correspondence:}

Dr Nwachukwu Prince Ololube, Oloify Consulting Company, Research, Education Effectiveness and Quality Improvement Consultants, P.O. Box 135, Ahoada, Rivers State, Nigeria. Email: ololubeprince@yahoo.com

Received 19 January 2008; revised version received 9 April, 2008 